\title{
An exploration of the role of intuitive forms of planning in the succession process: the explanatory power of effectuation theory
}

\author{
Mira Bloemen-Bekx
}

Hanze University of Applied Sciences, Groningen, The Netherlands

Frank Lambrechts

Faculty of Business and Economics, Hasselt University, Hasselt, Belgium, and

Anita Van Gils

School of Business and Economics, Maastricht University, Maastricht, The Netherlands

\begin{abstract}
Purpose - This study explores how and when intuitive forms of planning can be used in a family firm's succession process.

Design/methodology/approach - The study uses an extended focus group meeting, consisting of individual, group and subgroup discussions with seven highly experienced external family business advisors in the Netherlands to gain a holistic understanding of the succession process and its underlying logic. The study also employs pre- and post-group questionnaires.

Findings - This study reveals that advisors perceive intuitive forms of planning as an integral part of the succession process, with the latter containing both intuitive and formal logic and activities. Both logics are used situationally and flexibly to deal with the uniqueness and unpredictability of the succession process and to build strong relations and manage relational dynamics in business families to address tasks, dilemmas and contingencies.

Originality/value - The succession process is an important part of business families' achievement of transgenerational intent. Creating commitment among potential successors begins when they are children, and understanding the role of the more intuitive forms of planning during the succession process will provide us with a more holistic perspective on its dynamics.
\end{abstract}

Keywords Succession planning, Effectuation, Intuitive planning

Paper type Research paper

\section{Introduction}

The literature defines "succession" as a multi-phase and multi-stakeholder process comprised of actions and events that lead to the transfer of leadership and/or ownership from one family business generation to another (Daspit et al., 2016; Long and Chrisman, 2014). Researchers argue that succession is a strategic and long-term process that needs to be planned carefully and with the proper timing to be successful (Daspit et al., 2017; Eddleston et al., 2013). Past

(C) Mira Bloemen-Bekx, Frank Lambrechts and Anita Van Gils. Published by Emerald Publishing Limited. This article is published under the Creative Commons Attribution (CC BY 4.0) licence. Anyone may reproduce, distribute, translate and create derivative works of this article (for both commercial and non-commercial purposes), subject to full attribution to the original publication and authors. The full terms of this licence may be seen at http://creativecommons.org/licences/by/4.0/legalcode

The authors acknowledge and thank FBNed Netherlands and the family business advisors in the focus group for sharing their knowledge.
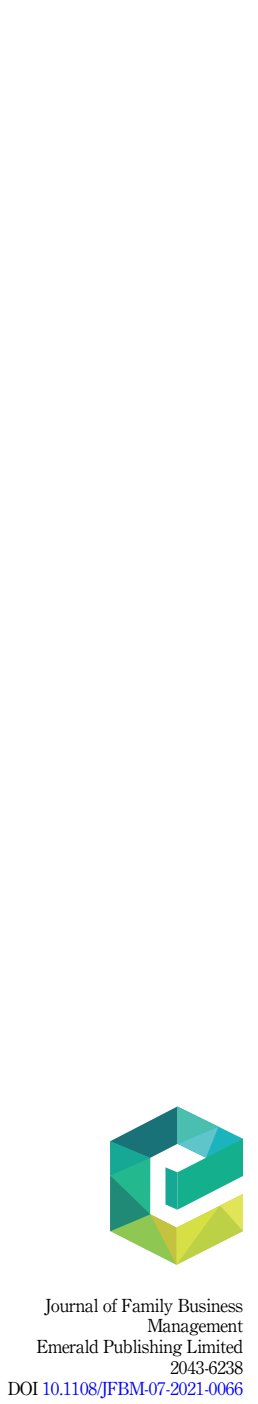
findings show that business families generally start to plan when a trusted successor is available (Sharma et al., 2001) but rarely identify a successor within the five-year period before the incumbent's expected retirement date (Feltham et al., 2005).

The research shows that business families are reluctant to plan in the early phases of the succession process and seem to prefer "intuitive" forms of planning over formal planning procedures (Daspit et al., 2016, p. 53; Kirby and Lee, 1996; Meier and Schier, 2016). Intuitive forms of planning can be defined as "sophisticated and nuanced" ways of thinking about the uncertainty of the future based on an awareness of contextual conditions such as contingencies and countervailing factors, which may lead to unexpected outcomes (Derbyshire and Wright, 2017, p. 255). Succession processes are important in enabling business families to attain their transgenerational intent (Habbershon and Pistrui, 2002). Creating commitment among potential successors begins when they are young (Bloemen-Bekx et al., 2021), but the role of more intuitive forms of planning during the succession process has been largely overlooked in the literature (Daspit et al., 2016), perhaps because intuitive forms of planning are less easy to study due to their implicit nature (Calabrò and Mussolino, 2013; Bloemen-Bekx et al., 2021). Addressing this gap and strengthening our understanding of the value of intuitive forms of planning will provide researchers, advisors and families with a more holistic view of the processes required to transfer the family business successfully.

To address this research problem, we introduce effectuation theory-a decision-making logic adopted in uncertain contexts (Sarasvathy, 2001)-as a theoretical lens in order to enhance our understanding of the use of intuitive forms of planning in family businesses. Effectuation theory distinguishes between two modes of entrepreneurial behavior: causation and effectuation. Causation is a collective term for strategic theories that "take a particular effect as given and focuses on selecting between means to create that effect" (Sarasvathy, 2001, p. 245). It consists of activities such as goal orientation, rational analysis and formal planning (e.g. Brinckmann et al., 2010). The causation process follows a logic similar to that described in the literature on formal succession planning. An effectual logic may satisfactorily explain the intuitive part of the succession process. Effectuation "takes a set of means as given and focuses on selecting between possible effects that can be created with that set of means" (Sarasvathy, 2001, p. 245). In other words, potential scenarios are evaluated based on the available resources and capabilities. In this study, we argue that effectual (intuitive) and causal (formal) logics and related activities can both be used in the succession process, depending on the phase and circumstances of the process. Building on this theoretical rationale, we address the following research question: "How and when are intuitive and formal forms of planning used in a succession process that evolves over time?" Studying succession as a process involving both causation and effectuation logics and related activities may provide a more holistic understanding of it. Therefore, we performed an exploratory study among family business advisors with extensive experience in advising business families (Nordqvist et al., 2009). Data were gathered from an in-depth focus group with seven trusted content and process advisors and through pre- and post-group questionnaires (Strike, 2012; Michel and Kammerlander, 2015; Kubíček et al, 2019; Bertschi-Michel et al., 2021).

Our results show that intuitive forms of planning are used to deal with the uniqueness and unpredictability of the succession process and to build relationships and manage relational dynamics when the family is facing specific tasks, dilemmas and/or contingencies. Formal forms of planning are used to orient the business family toward the goal of the succession process, to build a governance system and to plan formal tasks in a timely fashion. Thus, formal and intuitive logics are used situationally and flexibly.

\section{Theoretical background}

\subsection{Succession process and planning}

The succession process has received much attention from family business researchers (Daspit et al., 2016; Sharma et al., 2003, 2012; Sharma and Irving, 2005). Succession planning, 
often defined as "a deliberate and formal process that facilitates an effective transfer of management control from one family member to another" (Mazzola et al., 2008, p. 241), is difficult because the periods in which families and non-family stakeholders typically need to make tough decisions are emotional and uncertain (Daspit et al., 2016, 2017). Consequently, family business owners tend to postpone working on succession explicitly (Astrachan and Kolenko, 1994).

Family businesses are often advised to take a strategic approach to planning the succession process (Daspit et al., 2016, 2017; Eddleston et al., 2013) to safeguard the goals of family harmony and business continuity (Upton et al., 2001). Strategic planning "entails the specification of goals and fosters the identification of effective steps to achieve these goals. Planning enables firms to control goal achievement” (Brinckmann and Kim, 2015, p. 27). Research has shown that a shared succession plan among family members is conditional on the long-term success of the business (Sharma et al., 2003; Sharma and Rao, 2000). A succession plan details a set of activities, provides clarity, and reduces ambiguity and conflict (Brun de Pontet et al., 2007). The commonly used integrative model of effective familyowned business succession formulated by Le Breton-Miller et al. (2004) proposes that the succession process should begin with the formalization of ground rules in a succession plan that will be communicated and adjusted with time, experience and feedback. The next three phases-nurturing/development (formal education, career development, training and interpersonal skills), selection (criteria, selection committee and selection) and transfer (timing and nature of phasing in/out, bridging period and transfer of capital)-follow a linear manner. This model is built on the tenets of strategic management, implying a formal planning logic suitable for goal setting and decision-making in stable and predictable environments, which allows for a gradual and safe hand-off process (Daspit et al., 2017). Although the authors acknowledge that a turbulent environment may require another style (Le Breton-Miller et al., 2004), they are silent on how this turbulence affects the succession process over time and its underlying decision-making logic.

Management and entrepreneurship scholars have questioned the value of formal planning in uncertain and unpredictable environments (Brinckmann et al., 2010; Derbyshire and Wright, 2017; March, 1991; Mintzberg, 1994). They propose an intuitive or adaptive approach to planning and suggest that organizations can focus on learning and pursuing flexible pathways to face dynamic external conditions. The research on succession planning has shown that its degree of formality is related to the distinctive challenges faced by family businesses at different generational stages of their development (Eddleston et al., 2013). For example, due to their prior experience, second- and third-generation family firms appear to plan successions more often and precisely than first-generation family businesses do (Sonfield and Lussier, 2004). In addition, formal planning seems to be more successful in the later phases of the process, such as when an able and trusted successor is willing to take over (Sharma et al., 2003). Formal planning procedures can facilitate an official handoff by offering contractual arrangements and role clarity to those involved (Daspit et al., 2016). Alternatively, intuitive forms of planning appear to be more appropriate in the uncertain, early phase in the process, when the hand-off remains far in the future. Family business owners with an intergenerational intent engage in activities that take place in the family context and are based on parent-child relationships (Daspit et al., 2016). The research has shown that family business owners can nurture a cohesive family structure and commitment to the family business, cultivate trust and loyalty among family members, and enhance communication (Bloemen-Bekx et al., 2021; Garcia et al., 2019; Royer et al., 2008; Sharma et al., 2003). Family business owners seem to prefer intuitive processes because they feel that formal activities are less suitable. Furthermore, at any time during the succession process, contingencies can arise that may require a more intuitive or formal approach. Such contingencies can come in many forms, and may be individual-, relational-, financial-, business- or process-related 
(De Massis et al., 2008). Planned and unplanned activities can both act as triggers that set off a switch in intuitive or formal logic (Brun de Pontet et al., 2007; Gersick et al., 1999; Le BretonMiller et al., 2004; Murray, 2003; Sharma et al., 2003). For example, a change in tax law with a fixed deadline can trigger a switch from an intuitive to a formal form of planning to secure a financially interesting transfer of ownership. Alternatively, a successor may withdraw from the succession process after a series of conflicts with the incumbent; this unplanned event may trigger a switch from a formal to an intuitive form of planning, as the incumbent has to reconsider his/her options. Contingencies, usually referred to as "complications" (De Massis et al., 2008), are an unavoidable part of the succession process and can alter its outcome.

We argue that the succession process cannot always be understood as a formal planned process and that intuitive forms of planning are essential for dealing with uncertain phases and contingencies. We seek to develop a more comprehensive understanding of the succession process and the role of intuitive forms of planning in it by introducing effectuation theory as an appropriate theoretical lens.

\subsection{Effectuation theory}

Effectuation is a theory used to understand the entrepreneurial process of decision-making in uncertain circumstances (Matalamäki, 2017; Perry et al., 2012; Sarasvathy, 2001). Effectuation theory provides a framework describing how entrepreneurs can reach their goals by using the available means to create commitment among stakeholders and deal with constraints along the way (Sarasvathy et al., 2014). Experienced entrepreneurs usually engage in effectuation processes because they are aware of the ineffectiveness of trying to forecast the future in unpredictable environments (Harms and Schiele, 2012; Matalamäki, 2017; Sarasvathy, 2001). Its logic is based on four guiding principles and one basic view: bird-inhand, affordable loss, crazy quilt, lemonade and pilot-in-the-plane (Sarasvathy et al., 2014). The bird-in-hand principle describes how the entrepreneur explores a variety of possibilities using the resources available here and now, which may eventually lead to the goal. The affordable loss principle describes what an entrepreneur can afford to lose (rather than hope to gain). Entrepreneurs know their environment best, and are thus capable of quickly assessing their affordable loss (Chandler et al., 2011). Generally, one should invest as much as one can afford to lose. The crazy quilt principle describes how the entrepreneur interacts with stakeholders in order to build strong relations, prevent loss, create opportunities, exchange resources and strengthen the processes at hand. In doing so, the entrepreneur prefers to engage with stakeholders who will share the risks of loss and the benefits of success (Chandler et al., 2011). The lemonade principle considers contingencies or surprises as opportunities that open up new avenues instead of threats that require more control (Sarasvathy et al., 2014). It has been shown that "acknowledging the unexpected" in R\&D processes positively influences their outcome (Brettel et al., 2012, p. 167). The basic pilot-inthe-plane view emphasizes the role of human action: the entrepreneur can intervene, transform and reshape processes involving stakeholders, but cannot control or predict them (Sarasvathy et al., 2013).

An effectuation process is dynamic and iterative, and aims to create new institutions. While the effectuation research focuses on the identification of effectual principles, the evidence increasingly suggests that effectuation is a process in which both effectual and causal logics occur (Berends et al., 2014; Jiang and Ruhling, 2017; Reymen et al., 2015). Indeed, effectuation theory sees effectual and causal logics not as opposed but as "integral parts of human reasoning that can occur simultaneously, overlapping and intertwining over different contexts of decisions and actions" (Sarasvathy, 2001, p. 245). Moreover, Jiang and Ruhling (2017) showed the heterogeneity of effectuation processes, challenging the assumption that effectuation processes unfold in similar ways. The scholars suggested that "effectuation 
processes are conditioned by sequences, combinations and iterations of effectuation and causation activities" (Jiang and Ruhling, 2017, p. 26). Therefore, periods of causation and effectuation can alternate (Nummela et al., 2014) or iteratively switch within phases (Berends et al., 2014; Sitoh et al., 2014). Thus, effectuation theory acknowledges the dynamic, complex, and often unpredictable nature of processes and recognizes the influence of risk perception, strong coalitions, contingencies and human action on outcomes.

Thus, the above discussion has shown that studying succession as a process comprising both causation and effectuation logics and activities may provide a more comprehensive understanding of the process.

\section{Method}

Our research questions led us to adopt an interpretative, qualitative approach using a focus group research design (Morgan, 1996). A focus group is "a research technique that collects data through group interaction on a topic determined by the researcher" (Morgan, 1996, p. 130). Focus groups with participants who have experience in and knowledge of the study topic assist in exploring research questions in depth and producing narratives that address professional or personal experiences over time (Duncan and Morgan, 1994).

We used the following selection criteria for our focus group: diversity (spread of content and process advisors), homogeneity (experience in complex succession processes) and high learning orientation (willingness to share; Davis et al., 2013; Morgan, 1996; Nordqvist et al., 2009; Strike, 2012). We teamed up with FBNed, the Dutch Association of Family Firms, to select focus group members with excellent track records in advising business families. Table 1 provides details on each of the advisors.

Data were collected in June 2019 at the head office of the FBNed in the Netherlands. The focus group meeting proceeded through four stages: one pre-group questionnaire, one focus group meeting of six hours and two post-group questionnaires involving all participants. The research design was based on an interpretative approach and focused on three central concepts: interpretation, meaning and understanding. During the focus group, two researchers were present; one researcher moderated the meeting, and the other researcher observed it. The moderator plays an important role in data collection when a focus group is used in an interpretative study (Morgan, 1996; Nordqvist et al., 2009). In this study, the moderator ensured a productive discussion and equal participation by providing group members with broad questions and assignments. After the meeting, the researchers reflected on their roles.

Before the focus group meeting, the researcher sent out a questionnaire with five preparatory questions to gather detailed knowledge about the participants and their advisory practices regarding succession. The questions concerned the start of the succession process, the moment of their involvement, the succession process in terms of time and phases, the separation between succession in ownership and management and decision-making throughout the process.

In the first part of the focus group meeting, each participant was given $10 \mathrm{~min}$ to present his/her answers to the five preparatory questions. During each presentation, the other focus group participants were asked to make notes. After the presentations, the group members asked explanatory questions and discussed the similarities and differences in their experiences with advising business families in succession processes. The aim of this discussion was to collect their experiences of succession processes first. This part took about two hours, was video and audio recorded, and was transcribed verbatim afterward (27 pages).

In the second part of the meeting, the researcher introduced effectuation theory to provide a theoretical anchor as well as to open up and broaden the discussion among the advisors, after which the participants were invited to discuss the theoretical framework. This part took 


\begin{tabular}{|c|c|c|c|c|c|c|c|}
\hline \multirow[t]{2}{*}{ JFBM } & Advisor & Sex & Education & $\begin{array}{l}\text { Nature of } \\
\text { company }\end{array}$ & Position & $\begin{array}{l}\text { Experience } \\
\text { in years }\end{array}$ & $\begin{array}{l}\text { Experience in } \\
\text { number of } \\
\text { family firms }\end{array}$ \\
\hline & A & M & $\begin{array}{l}\text { Master Business } \\
\text { Administration }\end{array}$ & $\begin{array}{l}\text { Family Business } \\
\text { Network }\end{array}$ & $\begin{array}{l}\text { Executive } \\
\text { Director/Family } \\
\text { Business } \\
\text { Advisor }\end{array}$ & 33 Years & $\begin{array}{l}104 \text { Advisory } \\
\text { processes }\end{array}$ \\
\hline & B & M & Master Tax Law & $\begin{array}{l}\text { Advisory, Tax } \\
\text { and Transaction } \\
\text { Services }\end{array}$ & $\begin{array}{l}\text { Partner/Chair of } \\
\text { Board of } \\
\text { Directors/Tax } \\
\text { Advisor }\end{array}$ & 28 Years & $\begin{array}{l}30-40 \\
\text { Advisory } \\
\text { processes }\end{array}$ \\
\hline & $\mathrm{C}$ & M & $\begin{array}{l}\text { Bachelor } \\
\text { Business } \\
\text { Administration }\end{array}$ & $\begin{array}{l}\text { Family Business } \\
\text { Consultancy }\end{array}$ & $\begin{array}{l}\text { Owner/Family } \\
\text { Business } \\
\text { Advisor }\end{array}$ & 13 Years & $\begin{array}{l}50 \text { Advisory } \\
\text { processes }\end{array}$ \\
\hline & $\mathrm{D}$ & M & $\begin{array}{l}\text { Bachelor } \\
\text { Business } \\
\text { Administration }\end{array}$ & $\begin{array}{l}\text { Family Business } \\
\text { Consultancy }\end{array}$ & $\begin{array}{l}\text { Owner/Family } \\
\text { Business } \\
\text { Advisor }\end{array}$ & 9 Years & $\begin{array}{l}28 \text { Advisory } \\
\text { processes }\end{array}$ \\
\hline & $\mathrm{E}$ & M & Master Law & $\begin{array}{l}\text { Strategic, } \\
\text { Corporate } \\
\text { Finance, } \\
\text { Restructuring and } \\
\text { Interim Services }\end{array}$ & $\begin{array}{l}\text { Managing } \\
\text { Director/ } \\
\text { Supervisory } \\
\text { Board Member } \\
\text { in FB }\end{array}$ & 20 Years & $\begin{array}{l}25 \text { Advisory } \\
\text { processes }\end{array}$ \\
\hline Table 1. & $\mathrm{~F}$ & M & Master Auditing & $\begin{array}{l}\text { Advisory, Tax } \\
\text { and Transaction }\end{array}$ & $\begin{array}{l}\text { Senior Family } \\
\text { Business }\end{array}$ & 21 Years & $\begin{array}{l}250-300 \\
\text { Advisory }\end{array}$ \\
\hline $\begin{array}{l}\text { Detailed information } \\
\text { on the Dutch family } \\
\text { business advisors in } \\
\text { the focus group }\end{array}$ & G & $\mathrm{F}$ & Master Tax Law & $\begin{array}{l}\text { Services } \\
\text { Advisory, Tax } \\
\text { and Transaction } \\
\text { Services }\end{array}$ & $\begin{array}{l}\text { Advisor } \\
\text { Partner/Family } \\
\text { Enterprise } \\
\text { Leader }\end{array}$ & 14 Years & $\begin{array}{l}\text { processes } \\
40 \text { Advisory } \\
\text { processes }\end{array}$ \\
\hline
\end{tabular}

approximately one hour. This discussion was also video and audio recorded and transcribed verbatim (six pages).

In the third phase, the participants were invited to visualize the "ideal" succession process and its underlying decision-making. To allow for a more in-depth discussion and make room for different perspectives, we divided the group into two groups: one group of four family business process advisors (A, C, D, E) and one group of three advisors, all active in auditing companies $(B, F, G)$. Each group was facilitated by a researcher, who asked clarifying and process questions to keep the participants focused on the topic. The two groups had very vibrant and in-depth discussions and were able to visualize the succession process. After these two sessions, the two groups presented illustrations of the process to each other. The researcher challenged them to establish a connection between the two illustrations, which resulted in a process model.

To end the focus group meeting, the researcher asked reflective questions to create a support base for the findings and conclusions. The advisors reported that they valued the interaction between theory and practice and had learned from each other. After the meeting, contact details were exchanged. This meeting took $2.5 \mathrm{~h}$, was video and audio recorded, and transcribed verbatim (63 pages).

A day after the focus group meeting, the researcher sent the first post-group questionnaire to the participants and invited them to reflect on the meeting. The participants returned the questionnaires, reporting that they looked back on a very positive and interesting meeting in which they were able to freely discuss the topic of study with knowledgeable colleagues. The participants reported that the theoretical perspective allowed them to challenge their daily 
practices. They also reported that, with the help of the other participants, they were able to create a process model of the succession process that reflects actual practice. The second postgroup questionnaire was sent about a month later, accompanied by written minutes of the discussion and the findings. This questionnaire validated the extent to which each participant agreed on the content of the discussion (procedure copied from Nordqvist et al., 2009). The participants agreed that the "Findings" section reflected their discussion and thought process. One participant reported that, although the process model was an exact copy of their work, it would still need additional thought.

We started analyzing our data inductively to identify emerging interpretations, meanings, language and understanding of the succession process (Nordqvist et al., 2009). The moderator of the focus group meeting carried out the analysis, while the observer checked the consistency of the analysis. We proceeded by bringing effectuation and causation into the data analysis process as "frames of interpretation" (Nordqvist et al., 2009, p. 299). Hence, we used empirical data and theory iteratively to gain insight into the theoretical framing of the succession process (Emerson, 2004). We wrote case reports on the group discussions to make our data accessible. The QDA Miner software program was used to prepare the materials for analysis. Following Nag et al. (2007) and Murphy et al. (2019), we looked for first-order, second-order and aggregated dimensions from an abductive perspective. To identify firstorder concepts, we read and analyzed the material from the focus group meeting. We let themes emerge freely while coding them in QDA Miner. Next, we clustered and analyzed each code by asking how each aspect would answer our research question. Second-order themes emerged as we questioned what these themes meant to family business advisors. We contrasted our findings with the visualization of the succession process as created by the focus group participants in order to "open up significant, often complex lines of conceptual development" (Emerson, 2004, p. 457), which led to the development of aggregated dimensions.

We aimed to ensure data quality by providing a clear research design (Morgan, 1996). Therefore, we created a realistic and detailed plan of the research process, carefully selected the focus group members using the above-mentioned criteria, developed pre- and post-group questionnaires, collected the data (done by two qualified researchers, the moderator and observer), followed a systematic analysis strategy and presented our findings in a comprehensible way (Morgan, 1996; Nordqvist et al., 2009). During this process, the mediator and observer took a reflexive attitude toward the focus group meeting, the participants, and the accounts produced, in that the mediator made "consistent and conscious efforts to view the subject matter from different angles" (Alvesson, 2010, p. 106). Thus, the transparency and thoroughness of our research design and the attitude of the researchers were aimed at enhancing the trustworthiness, relevance and usefulness of our study.

\section{Findings}

In this section, we first present our findings on how intuitive and formal logics are used. We use the tenets of effectuation theory (i.e. its four principles and one basic view) to report if and how intuitive forms of planning are used in the succession process. We also use the tenets of causation to study how formal planning forms are used. We then report our findings on when intuitive and formal logics are used. Then, we present a process model of the succession process, a co-creation of the advisors. Finally, we conclude by answering the research questions.

\subsection{Use of formal and intuitive forms of planning}

Our study reveals that formal and intuitive logics are both used in the succession process. We discuss formal forms of planning first, as the advisors argue that this is the starting point of a succession process. 
4.1.1 Formal forms of planning. Our findings reveal that goal orientation and formal task planning occur during the succession process. The advisors first addressed the need for a formal process structure as a precondition for succession process success. The advisors argued that a formal process structure can help business families during a succession. Advisor F said that it is important "to make a structured plan together and to find out how a succession process works, with a time path, and to plot several choice or decision moments." A process structure gives business families a sense of direction and order, a route and a mission with a broadly defined goal, without the need for detailed planning. Advisor E said the following:

Well, we depart from the harbor in Vlissingen to go to New York. New York is your next succession event. You plan to arrive in New York, but you cannot hold course because of the wind, storm, and hurricanes. You just know that you cannot stick to your plan. What you can say is, this is the plan, and you can draw the plan, and if something happens, you just have to adjust your plan and then you will be on course again.

A process structure provides some clarity regarding the various stakeholders involved in the process, all of which have different positions, roles and expectations. The advisors recommend developing ground process rules to guide business families in the succession process. The following is taken from discussions among the advisors:

Ground rules are more focused towards the process than the content (E). On processes, yes (A), and we must have a system based on these ground process rules, to deal with things which go wrong with the family, business, or management (E). You can write them down in the form of "rules of the game", you can arrange that. In terms of behavior. And the interesting part is that it says something about what the family finds important (D).

A process structure can help business families organize formal activities that facilitate consultation and decision-making among family and non-family stakeholders. To quote advisor A, "The challenge is to design a good governance system to discuss topics and make decisions. And when something goes wrong, you can rely on your governance." A clear governance system allows business families to discuss the family, ownership and business issues that arise during the process. This will encourage the participants to bring issues to the table, discuss and solve them with each other. Good decision-making and communication skills among family members are essential for a well-functioning governance system. To quote advisor G, "The earlier you start creating a culture in which you learn to communicate and make decisions with each other, the better it will work when the difficult issues are on the table, for instance selecting the next successor."

The advisors mentioned formal tasks that needed to be done at one point during the succession process, such as estate and financial planning, asset valuation, restructuring, tax law issues and formalities. The advisors all agreed that, although these more formal tasks often occur later in the process, some tasks can also occur in the early phase. To quote advisor E, "Ownership and management are often situationally disconnected, because a father can already have transferred the shares to the next generation for tax reasons."

4.1.2 Intuitive forms of planning. Our findings reveal ample evidence of intuitive forms of planning, which are used to deal with uncertainties such as contingencies and dilemmas, to build strong relationships and manage relational dynamics with the family during the succession process. The dominant factor in our findings is the role of contingencies in the succession process, providing ample evidence of the lemonade principle. The advisors talked about the many uncertainties and dilemmas within families that occur in the succession process and how their impact intensifies as the process unfolds. Several things may occur. First, contingencies may arise that can impact the succession process. For example, close to the succession event, the expected successor may meet the love of his life, who happens to live 
on the other side of the world; he may decide to emigrate rather than enter the family business. Often, these contingencies are environmental and contextual events that are beyond the families' control and may constrain or enhance the succession process. To quote advisor E, "For example, the situation in New York in 2001 and in Paris in 2015; we never thought something like that could happen." Other contingencies that were mentioned include economic failure and an unexpected offer for the business. Second, dilemmas can arise during the process. Their nature largely depends on the business family's situation. Dilemmas can occur because of the age or refusal to retire of the incumbent, diversity and cooperation issues within the family, differences in family values, unclear educational criteria for potential successors, inadequate successor capabilities and the distribution of shares. To quote advisor D, "You can help the family by providing insight into the possible dilemmas with which they will be confronted. And what are the conversations that they're not having but intuitively know that they should be having." For example, one among several brothers who want to become the chief executive officer (CEO) in the family business may be assessed as having insufficient abilities. Indeed, issues such as expectations and other sensitive topics must be addressed. To quote advisor A, "It is necessary for the process to deal with the elephants in the room (A)."

The bird-in-the-hand principle emerged when the advisors talked about the importance of keeping an open mind about the business family's options. Each family is unique in terms of human capital, business portfolio, and geographical and economic position: "As every family is unique, I cannot make a detailed blueprint, there is no point to it" (advisor D). Therefore, the advisors argued that intuitive logic can help business families keep an open mind, as the succession process is dynamic, contextual and unique-and its outcome is thus unpredictable.

The affordable loss principle is strongly connected to the business family's wish to maintain family harmony. The advisors talked about avoiding circumstances such as one in which "the grandfather and mother were not allowed to see their grandchildren again" (advisor E). The succession process is emotional due to the family involvement. Advisor A said, "I think there is too much emphasis in research, but also in practice, on the ratio, suggesting that the succession process is a controlled process, but it is not." The advisors acknowledged that advisors and families often pay little attention to the emotional aspects of the process. To quote advisor F, "It must be an emotional process, and you cannot see it otherwise because the family bond and the family relationships are emotional. And of course, there are rational components in the process and professional decision making needs to be done, but these emotional issues are just as important." One advisor discussed a case in which the business family had to decide on whether the children of his third wife, who were not his children by blood, could become owners. If a business family does not involve family members in the process, they risk creating resistance and conflict, and thus damaging family harmony. It is thus important for business families to act transparently during the process, and intuitive forms of planning are helpful in managing these family dynamics.

Evidence of the crazy quilt principle can be found in the need to build strong relationships within the family. Good communication among family members and other stakeholders is needed to build these relationships and allow the process to flow. To quote advisor C, "Communication is relevant during the whole process. It is basically the 'aorta' of the process." Communication based on intuitive logic can prevent resistance among stakeholders, make the process transparent, allow stakeholders to be heard and create a common base of understanding. To quote advisor F, "There is interaction, everyone needs to know what the other is doing. And they have to discuss with each other and communicate about the things they are doing."

Thus, intuitive logic is used to deal with the uncertain and unique nature of the succession process, build strong relationships and manage family dynamics to ensure family harmony. Our findings also show that formal forms of planning are used to orient the business family 
toward the goal of the succession process, build a governance system and plan formal tasks in a timely fashion.

\subsection{Timing of formal and intuitive logic and activities}

Our findings show that, although the advisors had divergent views on when the phases of a succession process begin and end, they all agreed on three main phases: ambition (phase 1), abilities (phase 2) and acceptance (phase 3). However, the advisors also stressed that the presumed linearity of the three phases is often not reflected in practice. Intuitive and formal logics and related activities can occur in different phases depending on the circumstances of the business family. In addition, expected and unexpected contingencies appear to weigh more heavily on the process as the official handover draws closer. To quote advisor D, "Time plays an important role, you rather look at the growing impact events have on the business and the family."

Regarding effectuation principles, contingencies (lemonade) play an important role in the succession process and cannot be linked to a specific phase. Contingencies are an integral part of the succession process as a whole.

Phase 1 of the succession process is initiated by human action via the pilot-in-the-plane basic view, wherein the business family can create urgency, start informal and formal discussions about the succession, and prepare a governance system. To quote advisor E, "in this phase, who has a say in it? For sure, if there is one CEO, he/she definitely has a say in it. In addition, we have the family, the shareholders, the supervisory board, a bank, external financiers. They all have a say in it." In addition, the business family can strengthen relations between stakeholders, using intuitive forms of planning to foster ambition for a role in the family business. Stakeholders can be either family or non-family members. To quote advisor G:

Who is involved? Practically everyone, also the personnel of the company who has to accept the decision. That is also, the incumbent, the successor, the management, the owners, the family members. Because you cannot do it on your own, it is not an individual trajectory. Some things in the succession process you cannot do alone, you need to do it with more people.

Therefore, bonding and binding activities, good communication skills and shared language among stakeholders are all important in the succession process. As advisor G said, "Doing this structurally together. You need to learn to communicate as a family, if you want to make choices together."

In phase 2, the business family develops scenarios to envision possible outcomes of the succession process, in an example of the bird-in-hand principle. The advisors argued that intuitive logic is used to explore these: "What do our children want? What do we want? What scenarios could work?" (Advisor D). In addition, the business family starts to engage in more formal planning activities, such as assessing the value of the company, possibly redesigning the company structure, formulating contracts and assessing the abilities of the successor. To quote advisor B, "Often, senior wants to assess the capabilities of the successor. That takes quite some time, this doubting. Can he do it or not, how do we do it? Do we need to involve his/her brother, how to proceed?'

In phase 3 , the role of human action (pilot-in-the-plane basic view) regains momentum. The advisors reported that, through intuitive logic and related activities, the successor takes on a leadership role and the incumbent finds new avenues for the future, while they jointly need to generate support for the new situation among the stakeholders. To quote advisor $\mathrm{B}$, "The succession ends when junior is not junior anymore." Formal activities such as the transfer of shares may also occur. 
Thus, intuitive and formal logics and related activities are used flexibly and situationally during the succession process depending on the specific family context, the different phase dynamics, and the diverse time orientations and interests among the stakeholders.

\subsection{Process model of succession process}

The findings described above were used by the advisors to co-create a process model of the succession process (see Figure 1). The process model starts with the heart, which represents family harmony. Formal forms of planning, directed towards goal orientation, are apparent in the governance system with its tables, which are used to communicate, consult, and decide on family, ownership, and business issues. Intuitive forms of planning are observed in the three phases, where the stakeholders are confronted with contingencies and dilemmas, which have an impact on the family, the business or the entrepreneur. Intuitive logic is used to deal with these environmental and contextual issues, focus on opportunities, and improve communication in order to build strong relationships and manage family dynamics. The three phases have multiple pathways with an entry and exit by which stakeholders may join or leave the succession process, depending on their ambition, abilities and acceptance.

4.3.1 Illustrative vignette of the process model. This vignette aims to clarify the role of intuitive and formal planning in the process model through hypothetical examples.

The process model was built on a well-functioning governance system. This formal system allows stakeholders to communicate, consult and decide during the succession process and thus let the process flow. The stakeholders must have a shared language and good communication skills. The system allows the stakeholders to use mostly intuitive logic and related activities to navigate through the process. For example, a question that poses a dilemma in Phase 1 (e.g. "Shall I tell my parents that I do not want to work in the family business?") can be discussed in an informal, intuitive way at the family governance table. Similarly, contingencies (e.g. an unexpected buyer for the business appears) can be addressed through formal reasoning at the family, business and ownership governance table. Formal

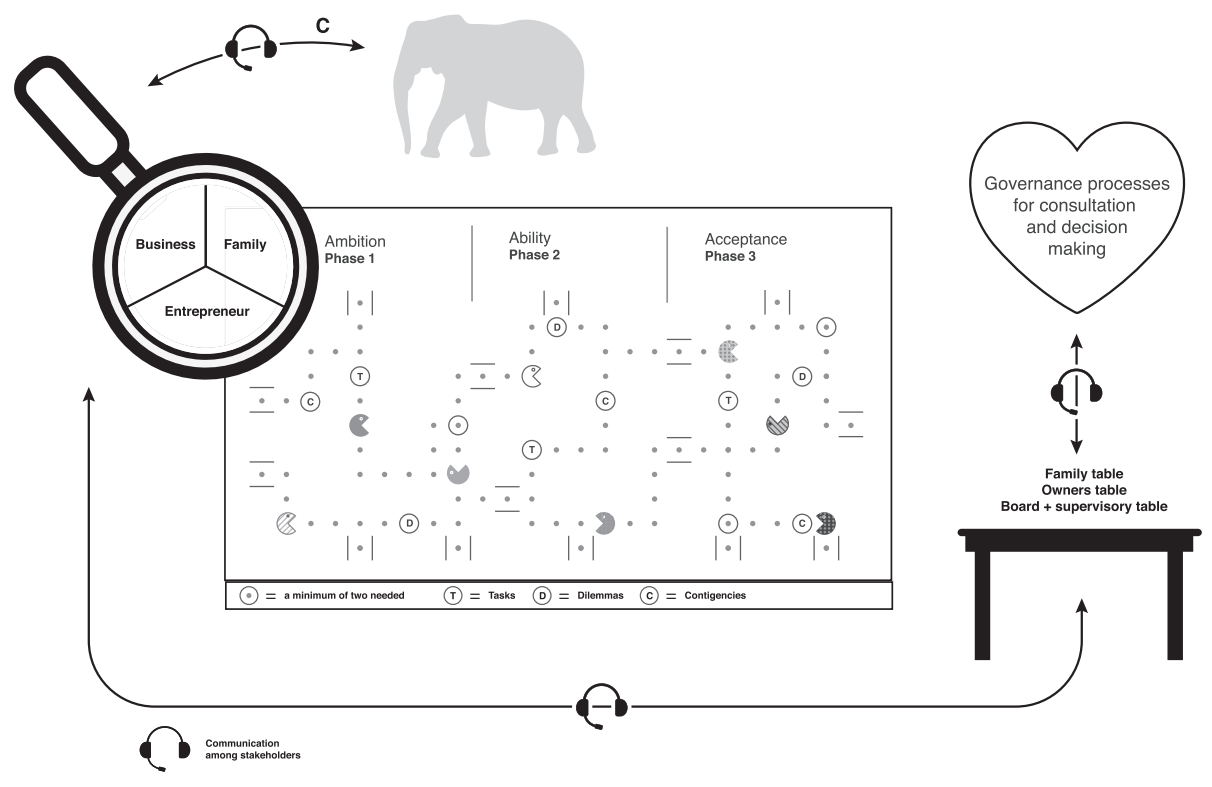

Succession process

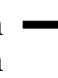


tasks are often planned. For example, a possible successor may receive additional training and undergo ability assessments in phase 2 . However, the outcome of these formal tasks may require more intuitive forms of planning, such as if a successor is not positively assessed or if only one out of three possible successors has the potential to become the CEO of the family business.

\section{Discussion}

This study has explored the role of intuitive forms of planning under the assumption that intuitive and formal logics are both used in succession processes. Our study provides initial evidence that intuitive forms of planning can be used to deal with contingencies and dilemmas during the long and uncertain succession process. It also highlights the need to develop strong relationships and manage the family dynamics necessary to nurture family harmony during the succession process. Formal forms of planning are used to create a formal governance system that helps the business family focus on the goal, perform formal tasks and navigate the process successfully. Intuitive and formal forms of planning seem to interact flexibly and situationally and can be used throughout the succession process, depending on the process phases and circumstances. Contrary to earlier findings (Daspit et al., 2016, p. 53; Kirby and Lee, 1996; Meier and Schier, 2016), we find that intuitive logic is not used only in the early phases of the succession process but adds value throughout the whole process. These findings provide meaningful contributions to the literature on pre-succession and succession. Furthermore, the practical perspectives of the advisors on the succession process revealed in this study challenge the widely held assumption that the process is predictive and strategic (e.g. Daspit et al., 2017; Dyck et al., 2002; Eddleston et al., 2013).

Effectuation theory has been shown to be an appropriate theoretical framework with which to investigate the role of intuitive logic in the succession process and to study the interaction between intuitive and formal logics. Due to coronavirus disease 2019 (COVID-19), we have become more aware of the disrupting impact of contingencies on daily practices and have realized more than ever that lives as well as processes do not follow linear pathways. Therefore, effectuation theory can be used in the family business literature as a more sophisticated and nuanced way of thinking about uncertainty and the impact of contingencies (Derbyshire and Wright, 2017).

Our process model contributes to research by providing a contemporary perspective on succession. Our process model has much in common with the integrative model of effective family-owned business succession formulated by Le Breton-Miller et al. (2004), but it differs in its underlying theoretical foundation. Although Le Breton-Miller et al. (2004) acknowledged that the succession process may change in hostile and turbulent times (Dyck et al., 2002) and included feedback loops to deal with surprises and uncertainty, the integrative model is built on studies that regard the succession process as formally planned (e.g. Handler, 1994; Ward, 1987). Our process model takes uncertainty as its starting point and provides a governance structure in which the business family can communicate, consult and decide on any topic (planned or unplanned) that arises during the succession process. Although the integrative model recognizes that close family relationships are important for family harmony, the model is silent on how it can help business families maintain that harmony. The value of our process model is that it is directed toward providing a governance system in which intuitive logic helps business families build strong relationships and manage family dynamics during the succession process. Further research is needed to strengthen our process model. Integrating the perspectives of family business leaders and their successors, as well as family business therapists and other types of advisors, is required to obtain a truly holistic overview of the succession process. 
Research has shown that $30 \%$ of family businesses transition to the second generation successfully and $13 \%$ transition to the third, while only $3 \%$ transition to the fourth in the Netherlands (ECFB et al., 2016). Thus, further scientific examination of succession is important. Our study points to other succession process narratives that can be told to families, owners, managers, supervisors, advisors, scholars, professors and students, hence providing an alternative to the prevalent stories of rational and formal planning in succession processes. For example, the process model, with its multiple pathways and entries and exits, offers the next generation the flexibility it needs to gain, strengthen, change, discuss and rethink its position in the succession process.

Our study is exploratory, showing initial theoretical and practical findings and implications in a geographically and culturally defined setting. Additional research is needed to extend the knowledge in this field. For example, research could be conducted on the role of intuitive logic in situations of primogeniture. Calabrò et al. (2018) show that business families with a high degree of social emotional wealth endowment are more likely to appoint a firstborn sibling as the successor. It would be interesting to investigate the role of intuitive logic in the succession process that leads family and non-family members to accept the choice of successor. Research on intuitive forms of planning could also be extended by studying business families in different cultural contexts. Given the growing heterogeneity of family compositions and patterns within and across cultures (Jaskiewicz and Gibb Dyer, 2017), it would be worth studying how intuitive logic is used in different family compositions and different parts of the world. Researchers could also investigate the role of contingencies and their possible positive outcomes. The research has typically discussed contingencies as factors that prevent intra-familial succession (De Massis et al., 2008). It would be interesting to investigate best practice cases to gain in-depth knowledge of how business families can transform threats into opportunities, allowing them to attain both their transgenerational intent and family wealth objective (Habbershon and Pistrui, 2002).

While we address an important topic, our study has limitations because of the scope of our exploratory research. Although the focus group composed of family business advisors provided dense and in-depth data, follow-up research among business families who have recently experienced succession processes is necessary to refine and validate our findings. Alternatively, one could take a critical perspective and challenge our findings by finding a case in which a business family was successful in transferring the business to the next generation without using a structured process or a combination of formal and intuitive logics. Indeed, some may say that family business advisors will advocate a process structure and governance because it is part of their business model. In addition, the unbalanced division between this study's male and female focus group members may have produced a bias. Although we performed a member check to ensure that the female and younger focus group member felt heard in the discussions, future research should aim to compose more balanced focus groups.

\section{Conclusion}

This study aimed to answer the research question, "How and when are intuitive and formal forms of planning used in a succession process that evolves over time?" Regarding the first question, our study found that intuitive logic is used in the succession process to deal with the uniqueness and unpredictability of each succession process and to build strong relationships and manage relational dynamics. Our findings also show that formal forms of planning are used to orient the business family toward the goal of the succession process, to build a governance system and to plan formal tasks in a timely way. Regarding the second question, we expected to find intuitive forms of planning in the early phase and formal forms of planning in the later phases of the succession process. However, our study revealed that 
intuitive forms of planning complement the formal forms in all phases of the succession process. The choice between intuitive and formal planning depends on the situation, task and dilemma at hand. Hence, they are used flexibly and in situ.

\section{References}

Alvesson, M. (2010), Interpreting Interviews, SAGE Publications, London.

Astrachan, J.H. and Kolenko, T.A. (1994), "A neglected factor explaining family business success: human resource practices”, Family Business Review, Vol. 7 No. 3, pp. 251-262.

Berends, H., Jelinek, M., Reymen, I. and Stultiëns, R. (2014), "Product innovation processes in small firms: combining entrepreneurial effectuation and managerial causation", Journal of Product Innovation Management, Vol. 31 No. 3, pp. 616-635.

Bertschi-Michel, A., Sieger, P. and Kammerlander, N. (2021), "Succession in family-owned SMEs: the impact of advisors", Small Business Economics, Vol. 56 No. 4, pp. 1531-1551.

Bloemen-Bekx, M., Van Gils, A., Lambrechts, F. and Sharma, P. (2021), "Nurturing offspring's affective commitment through informal family governance mechanisms", Journal of Family Business Strategy, Vol. 12 No. 2, 100309.

Brettel, M., Mauer, R., Engelen, A. and Küpper, D. (2012), "Corporate effectuation: entrepreneurial action and its impact on R\&D project performance", Journal of Business Venturing, Vol. 27 No. 2, pp. 167-184.

Brinckmann, J., Grichnik, D. and Kapsa, D. (2010), "Should entrepreneurs plan or just storm the castle? A meta-analysis on contextual factors impacting the business planning-performance relationship in small firms", Journal of Business Venturing, Vol. 25 No. 1, pp. 24-40.

Brinckmann, J. and Kim, S.M. (2015), "Why we plan: the impact of nascent entrepreneurs' cognitive characteristics and human capital on business planning", Strategic Entrepreneurship Journal, Vol. 9 No. 2, pp. 153-166.

Brun de Pontet, S., Wrosch, C. and Gagne, M. (2007), "An exploration of the generational differences in levels of control held among family businesses approaching succession”, Family Business Review, Vol. 20 No. 4, pp. 337-354.

Calabrò, A. and Mussolino, D. (2013), "How do boards of directors contribute to family SME export intensity? The role of formal and informal governance mechanisms", Journal of Management and Governance, Vol. 17 No. 2, pp. 363-403.

Calabrò, A., Minichilli, A., Amore, M.D. and Brogi, M. (2018), "The courage to choose! Primogeniture and leadership succession in family firms", Strategic Management Journal, Vol. 39 No. 7, pp. 2014-2035.

Chandler, G.N., DeTienne, D.R., McKelvie, A. and Mumford, T.V. (2011), "Causation and effectuation processes: a validation study”, Journal of Business Venturing, Vol. 26 No. 3, pp. 375-390.

Daspit, J.J., Chrisman, J.J., Sharma, P., Pearson, A.W. and Long, R.G. (2017), "A strategic management perspective of the family firm: past trends, new insights, and future directions", Journal of Managerial Issues, Vol. 29 No. 1, pp. 6-29.

Daspit, J.J., Holt, D.T., Chrisman, J.J. and Long, R.G. (2016), "Examining family firm succession from a social exchange perspective: a multiphase, multistakeholder review", Family Business Review, Vol. 29 No. 1, pp. 44-64.

Davis, W.D., Dibrell, C., Craig, J.B. and Green, J. (2013), “The effects of goal orientation and client feedback on the adaptive behaviors of family enterprise advisors", Family Business Review, Vol. 26 No. 3, pp. 215-234.

De Massis, A., Chua, J.H. and Chrisman, J.J. (2008), "Factors preventing intra-family succession", Family Business Review, Vol. 21 No. 2, pp. 183-199.

Derbyshire, J. and Wright, G. (2017), “Augmenting the intuitive logics scenario planning method for a more comprehensive analysis of causation", International Journal of Forecasting, Vol. 33 No. 1, pp. 254-266. 
Duncan, M.T. and Morgan, D.L. (1994), "Sharing the caring: family caregivers' views of their relationships with nursing home staff", The Gerontologist, Vol. 34 No. 2, pp. 235-244.

Dyck, B., Mauws, M., Starke, F.A. and Mischke, G.A. (2002), "Passing the baton: the importance of sequence, timing, technique and communication in executive succession", Journal of Business Venturing, Vol. 17 No. 2, pp. 143-162.

ECFB, BDO and Rabobank (2018), "Nieuw Bloed Nieuwe Koers", available at: www.erim.eur.nl (accessed 8 October 2021).

Eddleston, K.A., Kellermanns, F.W., Floyd, S.W., Crittenden, V.L. and Crittenden, W.F. (2013), "Planning for growth: life stage differences in family firms", Entrepreneurship Theory and Practice, Vol. 37 No. 5, pp. 1177-1202.

Emerson, R. (2004), "Working with 'key incidents", in Seale, C., Gobo, G., Gubrium, J.F. and Silverman, D. (Eds), Qualitative Research Practice, Sage Publications, London.

Feltham, T.S., Feltham, G. and Barnett, J.J. (2005), "The dependence of family businesses on a single decision-maker", Journal of Small Business Management, Vol. 43 No. 1, pp. 1-15.

Garcia, P., Sharma, P., De Massis, A., Wright, M. and Scholes, L. (2019), "Parental behaviors and nextgeneration engagement in family firms: a social cognitive perspective", Entrepreneurship Theory and Practice, Vol. 43 No. 2, pp. 224-243.

Gersick, K.E., Lansberg, I., Desjardins, M. and Dunn, B. (1999), "Stages and transitions: managing change in the family business", Family Business Review, Vol. 12 No. 4, pp. 287-297.

Habbershon, T.G. and Pistrui, J. (2002), "Enterprising families domain: family-influenced ownership groups in pursuit of transgenerational wealth", Family Business Review, Vol. 15 No. 3, pp. 223-237.

Handler, W.C. (1994), "Succession in family business: a review of the research", Family Business Review, Vol. 7 No. 2, pp. 133-157.

Harms, R. and Schiele, H. (2012), "Antecedents and consequences of effectuation and causation in the international new venture creation process", Journal of International Entrepreneurship, Vol. 10 No. 2, pp. 95-116.

Jaskiewicz, P. and Dyer, W.G. (2017), "Addressing the elephant in the room: disentangling family heterogeneity to advance family business research", Family Business Revie, Vol. 30 No. 2, pp. 111-118.

Jiang, Y. and Ruhling, C.-C. (2017), "Opening the black box of effectuation characteristics and dominant types", Entrepreneurship Theory and Practice, Vol. 43 No. 1, pp. 171-202.

Kirby, D.A. and Lee, T.J. (1996), "Research note: succession management in family firms in northeast England”, Family Business Review, Vol. 9 No. 1, pp. 75-85.

Kubíček, A., Dofkova, L. and Machek, O. (2019), "Advice-seeking process in family businesses: a qualitative study", Journal of Family Business Management, Vol. 11 No. 1, pp. 19-31.

Le Breton-Miller, I., Miller, D. and Steier, L.P. (2004), "Toward an integrative model of effective FOB succession”, Entrepreneurship Theory and Practice, Vol. 28 No. 4, pp. 305-328.

Long, R.J. and Chrisman, J.J. (2014), "Management succession in family business", in Melin, L., Nordqvist, M. and Sharma, P. (Eds), The SAGE Handbook of Family Business, SAGE Publications, London.

March, J.G. (1991), "Exploration and exploitation in organizational learning", Organization Science, Vol. 2 No. 1, pp. 71-87.

Matalamäki, M.J. (2017), "Effectuation, an emerging theory of entrepreneurship-towards a mature stage of the development", Journal of Small Business and Enterprise Development, Vol. 24 No. 4, pp. 928-949.

Mazzola, P., Marchisio, G. and Astrachan, J. (2008), "Strategic planning in family business: a powerful developmental tool for the next generation”, Family Business Review, Vol. 21 No. 3, pp. 239-258. 
Meier, O. and Schier, G. (2016), "The early succession stage of a family firm: exploring the role of agency rationales and stewardship attitudes”, Family Business Review, Vol. 29 No. 3, pp. 256-277.

Michel, A. and Kammerlander, N. (2015), "Trusted advisors in a family business's successionplanning process - an agency perspective”, Journal of Family Business Strategy, Vol. 6 No. 1, pp. $45-57$.

Mintzberg, H. (1994), "The fall and rise of strategic planning”, Harvard Business Review, Vol. 72 No. 1, pp. 107-114.

Morgan, D.L. (1996), "Focus groups", Annual Review of Sociology, Vol. 22, pp. 129-152.

Murphy, L., Huybrechts, J. and Lambrechts, F. (2019), “The origins and development of socioemotional wealth within next-generation family members: an interpretive grounded theory study", Family Business Review, Vol. 32 No. 4, pp. 396-424.

Murray, B. (2003), "The succession transition process: a longitudinal perspective", Family Business Review, Vol. 16 No. 1, pp. 17-33.

Nag, R., Corley, K.G. and Gioia, D.A. (2007), "The intersection of organizational identity, knowledge, and practice: attempting strategic change via knowledge grafting", Academy of Management Journal, Vol. 50 No. 4, pp. 821-847.

Nordqvist, M., Hall, A. and Melin, L. (2009), "Qualitative research on family businesses: the relevance and usefulness of the interpretive approach", Journal of Management Organization, Vol. 15 No. 3, pp. 294-308.

Nummela, N., Saarenketo, S., Jokela, P. and Loane, S. (2014), "Strategic decision-making of a born global: a comparative study from three small open economies", Management International Review, Vol. 54 No. 4, pp. 527-550.

Perry, J.T., Chandler, G.N. and Markova, G. (2012), "Entrepreneurial effectuation: a review and suggestions for future research", Entrepreneurship Theory and Practice, Vol. 36 No. 4, pp. 837-861.

Reymen, I.M., Andries, P., Berends, H., Mauer, R., Stephan, U. and Van Burg, E. (2015), "Understanding dynamics of strategic decision making in venture creation: a process study of effectuation and causation", Strategic Entrepreneurship Journal, Vol. 9 No. 4, pp. 351-379.

Royer, S., Simons, R., Boyd, B. and Rafferty, A. (2008), "Promoting family: a contingency model of family business succession”, Family Business Review, Vol. 21 No. 1, pp. 15-30.

Sarasvathy, S.D. (2001), "Causation and effectuation: toward a theoretical shift from economic inevitability to entrepreneurial contingency", Academy of Management Review, Vol. 26 No. 2, pp. 243-263.

Sarasvathy, S.D., Kumar, K., York, J.G. and Bhagavatula, S. (2014), "An effectual approach to international entrepreneurship: overlaps, challenges, and provocative possibilities", Entrepreneurship Theory and Practice, Vol. 38 No. 1, pp. 71-93.

Sarasvathy, S.D., Menon, A.R. and Kuechle, G. (2013), "Failing firms and successful entrepreneurs: serial entrepreneurship as a temporal portfolio", Small Business Economics, Vol. 40 No. 2, pp. 417-434.

Sharma, P. and Irving, P.G. (2005), "Four bases of family business successor commitment: antecedents and consequences", Entrepreneurship Theory and Practice, Vol. 29 No. 1, pp. 13-33.

Sharma, P. and Rao, A.S. (2000), "Successor attributes in Indian and Canadian family firms: a comparative study", Family Business Review, Vol. 13 No. 4, pp. 313-330.

Sharma, P., Chrisman, J.J., Pablo, A.L. and Chua, J.H. (2001), "Determinants of initial satisfaction with the succession process in family firms: a conceptual model", Entrepreneurship Theory and Practice, Vol. 25 No. 3, pp. 17-36.

Sharma, P., Chrisman, J.J. and Chua, J.H. (2003), "Succession planning as planned behavior: some empirical results", Family Business Review, Vol. 16 No. 1, pp. 1-15. 
Sharma, P., Chrisman, J.J. and Gersick, K.E. (2012), "25 Years of family business review: reflections on the past and perspectives for the future", Family Business Review, Vol. 25 No. 1, pp. 5-15.

Sitoh, M.K., Pan, S.L. and Yu, C.-Y. (2014), "Business models and tactics in new product creation: the interplay of effectuation and causation processes", Transactions on Engineering Management, Vol. 61 No. 2, pp. 213-224.

Sonfield, M.B. and Lussier, R.N. (2004), "First-, second-, and third-generation family firms: a comparison”, Family Business Review, Vol. 17 No. 3, pp. 189-201.

Strike, V.M. (2012), "Advising the family firm: reviewing the past to build the future", Family Business Review, Vol. 25 No. 2, pp. 156-177.

Upton, N., Teal, E.J. and Felan, J.T. (2001), "Strategic and business planning practices of fast growth family firms", Journal of Small Business Management, Vol. 39 No. 1, pp. 60-72.

Ward, J. (1987), Keeping the Family Business Healthy; How to Plan for Continuing Growth, Profitability, and Family Leadership, Jossey-Bass, San Francisco, California.

\section{Corresponding author}

Anita Van Gils can be contacted at: a.vangils@maastrichtuniversity.nl

For instructions on how to order reprints of this article, please visit our website:

www.emeraldgrouppublishing.com/licensing/reprints.htm

Or contact us for further details: permissions@emeraldinsight.com 